\author{
第 1 編 \\ 赤血球 内 Bile Pigment Precursors $の$ 微 量 \\ 定量法の検討及び実験的考察 \\ 阙山大学医学部第一内科教宣 (主任: 小扳淖夫教授) \\ 㕦学㜔 中川昌壮
}

〔昭和 35 年 9 月 30 日受稿〕

\section{I. 赫言}

生体内に於て，血色来加ら胆汁色突加形成される 場所は古くより網内皮系の細胞，主に肝猫，脾捗，

骨骾のそれであるとされているが，著者の教空にお いては長年の間この生体内胆汁色桨生成部位の閭题 の解明が䄯りられた結果，最も主要な部位は肝臟実 質細胞であることが明らかとなつた1．又出血氷そ の他の血䈏外に逸脱した血液即与肋膜液中或いは犬 胎盤中において胆汁色素の形成が行なわれることも 諗められている2)。

一方, 流血中或注保存血中の生学赤血球内での

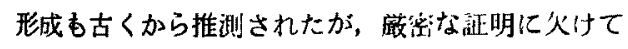
いた. 即ち Czike, A.3) 杖保存血液の血漿山bili-

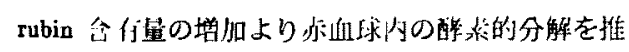
定し, Watson, C. J. \& Paine, J.A.4) は剔们蜰に

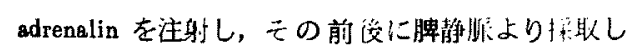
た血液の血色灵濃度の差を検討し脾脿詝留中に於け る赤血球内血色素の分解を推定している.

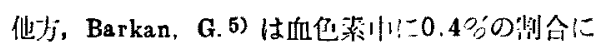

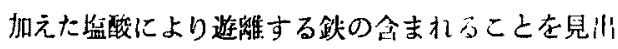
し, これを“easily split off blood iron”(以下少 分離鉄と呼称する.）と命名してから，その本態を 追及し，遂にてれが血皆头の胆汁色添への分解中間 産物である pseudohemoglobin (Barkan6)) に由米 すると唱え，赤血球中で血色米の成枝の行なわれる ことを㘳張した。

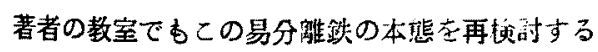

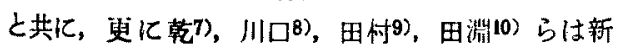

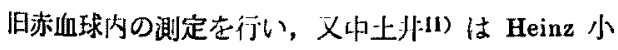
体の些成の而より，北川12》 は siderocyte の止成の

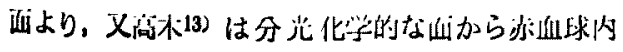

血色类崩填を検行し，それぞれ赤血球内血色奖分解 の可能性を実証している。

更に，Lemberg， R. 52)(4)15) は赤血球を酸処理 し, 彼等が choleglooin と命名した赤血球内 bile pigment precursors (以下 B. P.P. と略す) の定量 万法考案し，生存赤血球内の B.P.P. を测定し た結果, 常に含有血色装の約 1960 B.P.P. 加存 在することを明らかにした，二の後本测定法におい ての添加する $l$-ascorbin 酸その他の抽仙測定条件 が Gardikas, C. 16)17) と Lemberg. R. 15) との间に 諭議され, Gardikas, C. の詳細な测定法の確方に よりその含有望がやや多すきるにして无一闷

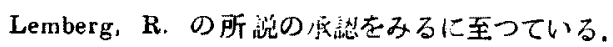

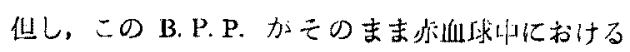

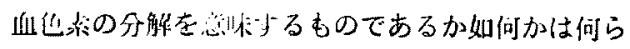

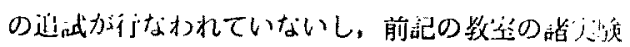

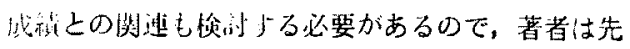
亦血球中の B. P.P.の抽泋条件, 微量定量法の

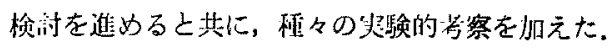

\section{II．実験方法及びその検討}

\section{1. 実験材料}

\section{1. biliverdin}

Lemberg，R.18）の才j法により，Merck 製維消

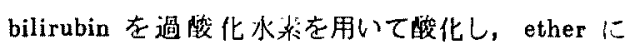
て拟设後絬战し，以にこれを再結思したすのを使用

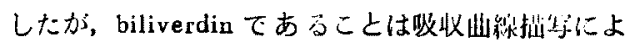
り確就した。

\section{2. ethyl ether}

天度カリ測粉父心により過酸化物の泥仙しないこ

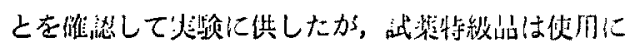
嘼した。 


\section{2. 実験方法}

2.1. 赤血球内 bile pigment precursors 抽出法 Gardikas, C., Kench, J. E. \& Wilkinson, J. F. 17) の方法に準じた，即ち，B.P. P.を醋酸中で biliverdinとなし，ether に抽出した，この ether 噟を醋 酸ソーダで洊湤して醋酸を除去し, 更に水洗して微 量の醋酸塩を取除いた。最後に ether 首より $5 \%$ $(W / v)$ 及び20\% (W/V) 塩酸で biliverdin 及び bilipurpurin を抽出した。

即ちをの詳細はFig. 1 亿图示する如くで， （a）生理的食塩水にて 3 回洗淮後 packed erythrocytes $5 \mathrm{ml}$ に怎溜水 $25 \mathrm{ml}$ を添加して䧄血を起す。 （b）水醋酸 $50 \mathrm{ml}$ 添加した後，15分間放固して反 応させる.（c）ether $150 \mathrm{ml}$ を加えて緩や加振淔

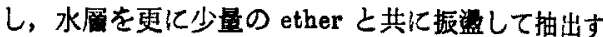
る.（d）と机らの ether 抽出液を先つ18\%醋酸り 一ダ溶波 $50 \mathrm{ml}$ で, 次いで $1.8 \%$ 醋酸ソーダ海液 $25 \mathrm{ml}$ で, 最後に蘶溜水 $50 \mathrm{ml}$ で洮潫する. (e) と の ether 首上り $5 \%(W / V)$ 塩酸，次いで20\%

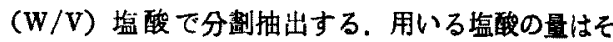
れぞれ 12〜20 ml であるが，緑色の着色の著明な

Fig. 1 Extraction Method of Bile Pigment Precursors in Erythrocytes (by Gardiras, C. et al. 17))

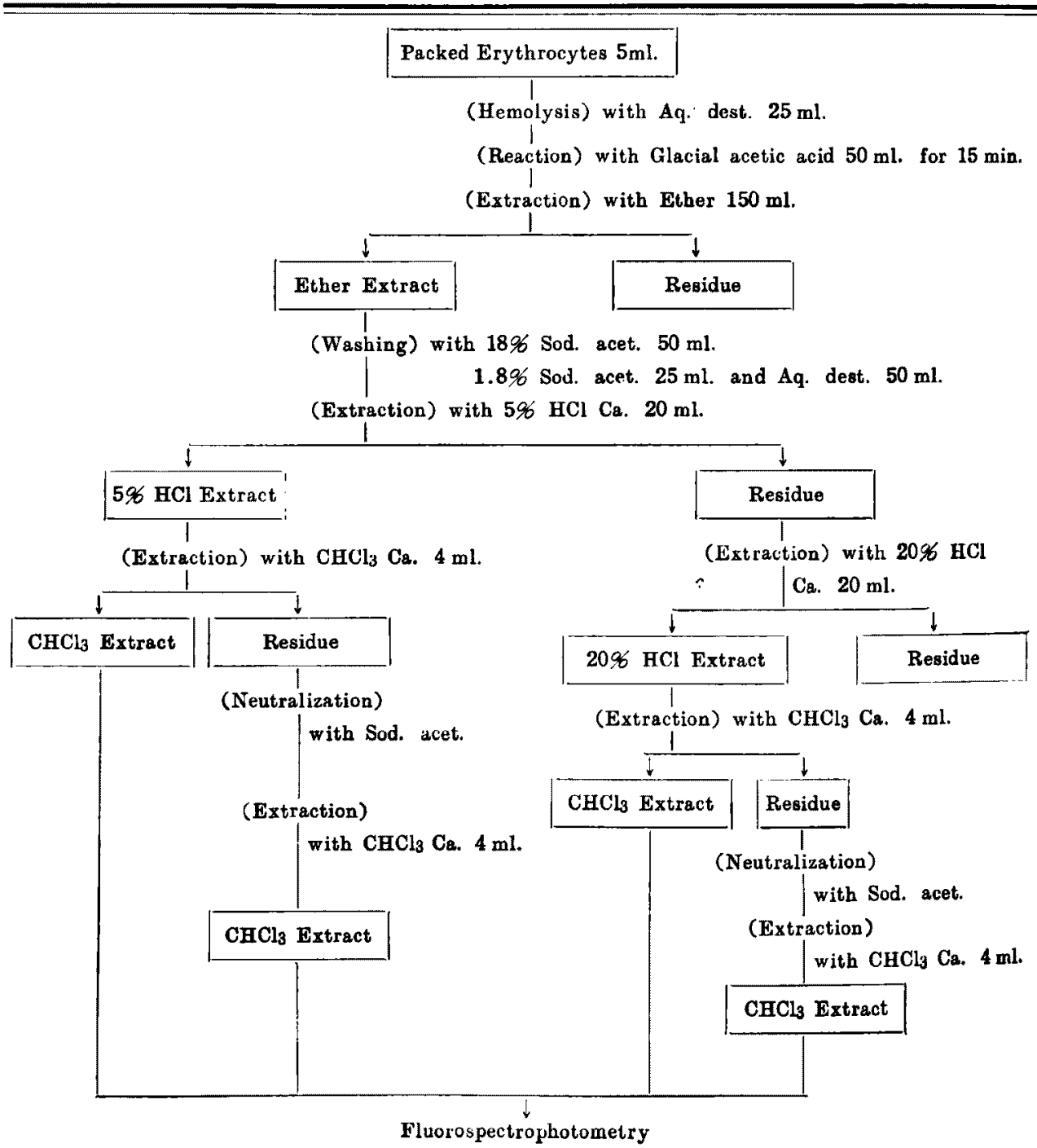


場合仕更に緑变しなくなるまで追加して抽出する。

\section{2. bile pigment の微富定盘法}

2. 2.1. bile pigment $\Phi$ chloroform へ捑仙 各々の塩酸抽出液より chloroform で抽出し，残 液に congo red 紙が青変しなくなる迄醋酸ソーダ を加えて中和して再び chloroform で抽出する，乙 れら chloroform 抽出㳊を合わせて㷵光定显汇用い る. 抽出に用いる chloroform の量はそれぞれ $4 \mathrm{ml}$ であるが，緑色着色の著明な場合は更に緑变を認め なくなるまで追加して抽出する。

\subsection{2. 螢光光度計に上る測定}

chloroform 抽出液 $2 \mathrm{mlk} 5 \%$ （W/V) 醋酸卧叙 methanol 溶液 $1 \mathrm{ml}$ を添加すると赤紅色螢光を発 するが，乙れは bilipurpurin 亜鉛錯塩に由来する と考えられる。

又 bile pigment の総量を定量するには, biliverdin を bilipurpurin に酸化するために更に戻度を加える 必要がある. 即 50.006\%(W/V) 沃度及び 0.008 $\%(W / v)$ 沃度カリの methanol 浴液 $0.06 \mathrm{ml}$ 添加する。

以上の両方の場合に発する螢光を日立製 EPU一 2 型分光々電光度計の螢光附属装置を用いて湖定し， 波長 $520 \mathrm{~m} \mu$ 亿於りるその microanmeter の指針 の䛃みを子小作成した㭘量曲稆により浱度に换算し て定量した。

\subsection{3. 㭘量曲楾の作成}

Lemberg， R. 18) の方法により調製した結晶 biliverdin hydrochloride を微量化学天科汇より秤量し $\tau$, 湿度 $10 \mu \mathrm{g} / \mathrm{ml}$ の骦準 biliverdin chloroform 溶液を作り, これより $0.1 \sim 10 \mu \mathrm{g} / \mathrm{ml}$ の径滥度の 波を調慗して上記 2.2.2. と同㥞の方法こ讧定して 伴成した。

Table I. Fig. 2. 次示如 $<, 0.1 \sim 5.0 \mu \mathrm{g} / \mathrm{ml}$ の範囲では洨度と螢光光度計の読みとの間汇㐤积的

Table $I$.

\begin{tabular}{l|llllllllll}
\hline $\begin{array}{c}\text { Biliverdin } \\
\begin{array}{l}\text { Concentra- } \\
\text { tion } \\
\mu \mathrm{g} / \mathrm{ml},\end{array}\end{array}$ & 0.1 & 0.2 & 0.4 & 0.6 & 0.8 & 1.0 & 1.5 & 2.0 & 2.5 \\
\hline $\begin{array}{l}\text { Microan- } \\
\text { meter }\end{array}$ & 1 & 3 & 8 & 10 & 15 & 19 & 30 & 37 & 48 \\
\hline $\begin{array}{c}\text { Biliverdin } \\
\text { Concentra- } \\
\text { tion } \\
\mu g / m l .\end{array}$ & 3.0 & 3.5 & 4.0 & 4.5 & 5.0 & 6.0 & 7.0 & 8.0 \\
$\begin{array}{l}\text { Microan- } \\
\text { meter }\end{array}$ & 55 & 66 & 71 & 80 & 86 & 97 & 103 & 111
\end{tabular}

Fig. 2. Calibration curve

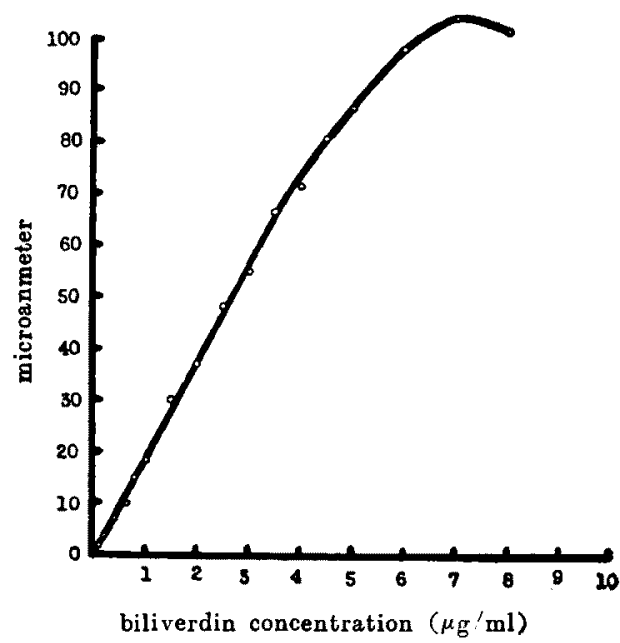

比例関係が琹められた。

2.3. 易分维跌（以下 E.S.Fe 之略す）量の测定 Barkan. G.の。-phenanthrolin 法に準じた教 室水戸の方法19）に上つた。就料は packed erythrocytes $0.5 \mathrm{ml}$ であり, 求めた鉄量は血色䕀 $1 \mathrm{~g}$ 当 りの量に换算して表吅した。

\section{3. 実験方法の検討}

3.1. 螢光定量法の娭討

3.1.1. filter（一次及び二次）の選抧

一次 filter 注装㯰满付けのもので, 主として $365 \mathrm{~m} \mu$ を透過し，可視光線を遮糸する，二次 filter としては，biliverdin choroform 溶液に醋酸严鉊 methanol 溶䍇及び沃度 methanol 溶波を添加して

Fig. 3. Fluorospectrophotometric Curve (biliverdin $\mathrm{CHCl}_{3}$ sol. $+\mathrm{Zn}$. acet. $+\mathrm{I}_{2}$ )

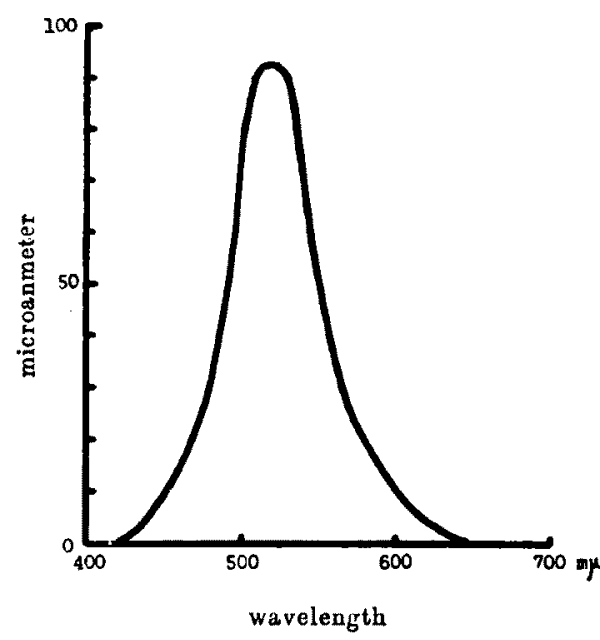


発する螢光の分光特性 が Fig. 3 亿示す如く 516〜 $520 \mathrm{~m} \mu$ に極大を有するので波長 $\operatorname{dial}$ を $520 \mathrm{~m} \mu$ に 合わせて测定した。

3.1.2, 溶液の $\mathrm{pH}$ と温度との関係

虫光定量に用いる試料の溶媒は chloroform であ り、この chloroform 溶液の $\mathrm{pH}$ を種々な值に調 節するととは困難である. 従つて biliverdin methanol 溶波において䝷光 $\mathrm{pH}$ 曲線を描き $\mathrm{pH} 7.0$ 附 近の中性の域に山を認め，それ以外の所ではかなり 急な勾配を有しているととを確かめたりれどす chloroform での螢光 $\mathbf{p H}$ 曲線の作成は失敗に終つ た.しかしながら上記の操作によつて得た chloroform 抽出波の $\mathrm{pH}$ は $\mathrm{pH}$ meter により測定した

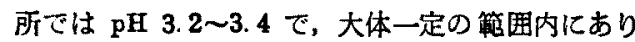
强酸性を示した。

測定温度は室温であるが，抽出 試料の酸化の可及的防止の目的娄 あつて室内の高盜時はなるへく避 けた.

3. 1. 3. 虫光独度の経時变化 biliverdin chloroform 溶液に 醋酸严鉊及び庆度の methanol 溶 液を加えて発する赫紀色䖝光は 紫外線照射により急速に橙黄 $\rightarrow$ 緑 黄 $\rightarrow$ 緑色に変色し，更に照射を㓍 けると遂に緑色螢光も消煺して族 青色に変わつてゆく，との際螢光 光度計の波長 $520 \mathrm{~m} \mu$ に於ける読 みも初めは次第に上暑していくか，

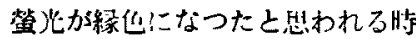

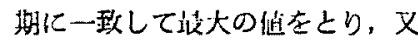

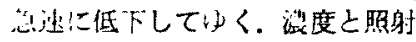

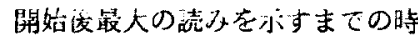
間との関係は濃度の增大と共に時 間あ延長する。

この粶色䖝光の物筫は何である

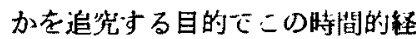
過を追つて Beckman DK 型自記

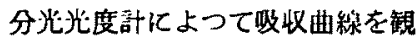
察与ると，Fig. 4 に亦扵上うに 変化してゆく，即ち biliverdin chloroform 溶液の波言 635,380 $\mathrm{m} \mu$ D㠷收植大（曲維1.) は 5 \% 醋酸亚除 methanol 浴液の添加の

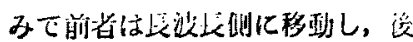

者は高さが低下する（曲線2）．更に沃度 methanol 溶液を加えると次第に $635 \mathrm{~m} \mu$ に一過性の山を表わ した後に低下する。それと共に $510 \mathrm{~m} \mu$ に一過性の 山を表わした後に低下する。それと共に $510 \mathrm{~m} \mu$ に 著明な極大を表わす（曲楾 3〜6).とれらの吸收 曲線において，初めの $635 \mathrm{~m} \mu$ の極大は biliverdin の酸化によつて生した bilipurpurin の亜鉊錯塩によ るものであり,後の $510 \mathrm{m \mu}$ の極大はこの bilipurpurin の醎化物である choleterin の亜鉊錯壏によるる のと考えられる。

次にこの様な吸収曲線上の変化を示す過程を螢光 分光曲穆の上から検討しようと努かたか，紫外線照 射の下ではこの変化がかなり急速に進行するために 困難である．しかし，赤血球からの抽出溜を試料と する場合は比較的に楥慢であるのでその場合の変化

Fig. 4. Changes of Absorption Spectra of Biliverdin $\mathrm{CHCl}_{3}$ Solution after Adding $\mathrm{Zn}$. acet. and $\mathrm{I}_{2}$ Methanol Solution during the Exposure to Ultraviolet Light.

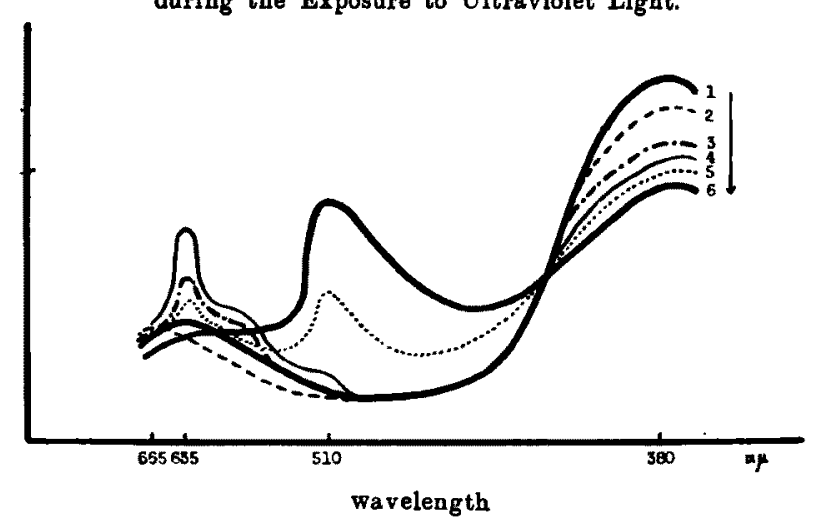

Fig. 5. Changes of Fluorospectrophotonetric Curves of $\mathrm{CHCl}_{3}$ Extract after Adding $\mathrm{Zn}$. acet. and $\mathrm{I}_{2}$ Methanol Solution during the Exposure to Ultraviolet Light.

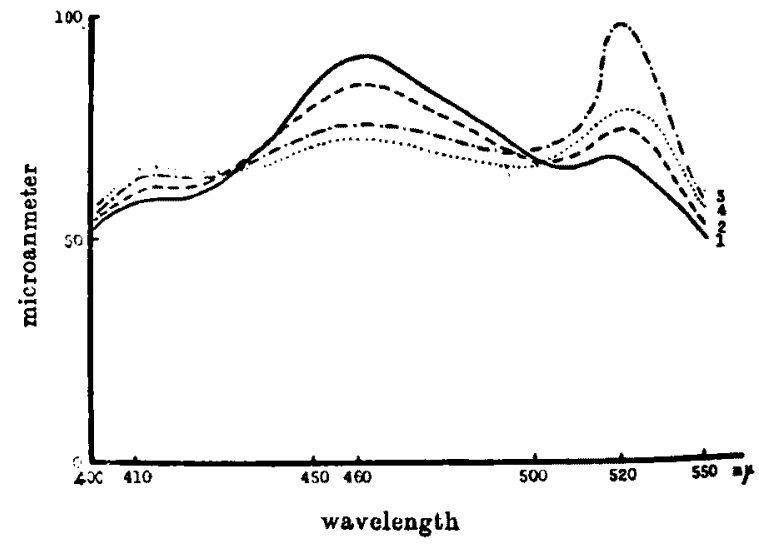


をみると，Fig. 5.K示す如く，初好 460〜 470 m に極大を証めるが，柴外称照射時問と共に515～520 $\mathrm{m} \mu$ に極大を生じ， $460 \sim 470 \mathrm{~m} \mu$ の極大は低下或 は消失するに至る，尚，biliverdin に欧度を添加し て磁化する場合に, biliverdin が分解して dipyrrol $の$ bilifuscin に移行する可能性すあるので赤外部に 於ける吸収曲線に就いて検討をしてみたが，bilifuscinの生成は認められなかつた。

\section{2. 抽出条件の検討}

赤血球内の B.P.P. は極く微量である上に容易に 酸化されるために, Lemberg, R. 14), Gardikas, C.16) はその抽出に当つて antioxidant として $l$-ascorbin 酸を加したが，後に Gardikas，C.17）の指摘する 如〈，l-ascorbin 酸は oxyhemoglobin 2 coupled oxidation を起して速やかに choleglobin を生成す るので, l-ascorbin 酸の添加により過誤を生ずる危 院る考えられる。そこて Gardikas，C.17)らは antioxidant とし $l$-ascorbin 酸を添加する代りに全 操作を N2 gas 充満下におて完全嫌気下に行う方
法を提唱している。そこでこれらのう法の中最も合 理的な方法を吟味するため，全操作を Gardikas, C. らの才法に做い完全に誛気性条件で行う埸会，奵気 性条件下で行う塌合，乙れらに $l$-ascorbin 酸 $10 \mathrm{mg}$ を添加した埸合等で人，犬，家患の3利の赤血球に 就きその含有 B.P.P. 量を測定してみると，Table IIの如く程族間に有意の差は認められないが, 1）好気性，婰気性の如何を問わず， $l$-ascorbin 酸 添加例では非添加例に比して蓄明な堌量を来してい るととより， $l$-ascorbin 䤒添加により一部人為的に choleglobin が生成される可能性が考えられる.

2）好気性の埸合之嫌気性の場合において biliverdin : bilipurpurin の比を校へると, 好気性の場合の 方が遥かに小であり，操作中に biliverdin が bilipurpurin に移行することがうかがえる.3）反対に $l$-ascorbin 酸源加例之非添加例とで前者が著しく 大であり, l-ascorbin 酸が biiiverdin $の$ bilipurpurin 八の酸化を抑制することがわかる.

以上のことより赤血球内 B.P.P. の批出に当つ

Table II. Effect of the Conditions of the Extraction to the Yields of the Intracorpuseular Bile Pigments.

\begin{tabular}{|c|c|c|c|c|c|c|}
\hline \multirow{2}{*}{ No. } & \multirow{2}{*}{ Samples } & \multirow{2}{*}{ Condition of Extraction } & \multicolumn{3}{|c|}{ Bile Pigments $(\mu \mathrm{g} / \mathrm{Hb})$} & \multirow{2}{*}{$\frac{\text { biliv. }}{\text { bilipur. }}$} \\
\hline & & & total & biliverdin & $\begin{array}{l}\text { bilipurpu- } \\
\text { rin }\end{array}$ & \\
\hline 1 & human erythrocytes & aerobic & 16.32 & 1.63 & 14.69 & 0.11 \\
\hline 2 & $"$ & anaerobic ${ }^{\Delta}$ & 20.01 & 8.63 & 11.37 & 0.76 \\
\hline 3 & " & aerobic +ascorbic acid* & 34.89 & 21.11 & 13.78 & 1.53 \\
\hline 4 & $"$ & anaerobic $\Delta+$ ascorbic acid ${ }^{*}$ & 30.80 & 17.64 & 13.16 & 1.34 \\
\hline 5 & dog erythrocytes & aerobic & 16.80 & 1.64 & 15.16 & 0.11 \\
\hline 6 & $"$ & anaerobic $\Delta$ & 16.18 & 6.22 & 9.96 & 0.62 \\
\hline 7 & rabbit erythrocytes & anaerobic $\Delta$ & 15.70 & 6.42 & 9.28 & 0.69 \\
\hline 8 & " & anaerobic $\Delta+$ ascorbic acid* & 24.40 & 15.60 & 8.80 & 1.77 \\
\hline
\end{tabular}

ては $l$-ascorbin 酸を加えないいで $N_{2}$ ga8 を充満した 嫌気性条件下において行うのか最す妥当であると考 えられる.

従つて実殹方法の項で既道した抽出法のうち(a) の溶血前より(d) の終りまでの操作を Gardikas, C. らの方法に準して Fig. 6 に示すような䒾罚に於い て $\mathrm{N}_{2} \mathrm{gas}$ を充満した条件下で行つた。

尚，Fig. 6 に执いてC及びそれに附随する硝子 管の部分は著者の考案により附設したるので，操作 (b)，(c)，(d) に於りる廃液を順次比の部分で再抽 出を元つて操作上の遣失をなるべく防ぐためのすの
である。

\section{3. 回収試験及び Lemberg 氏因子の算出}

Lemberg, R.14) は羊赤血球に一定量の biliverdin を添加し，更に biliverdin の酸化を防ぐために $l$-ascorbin 酸を加えて抽出探作を行い52,6の回收率 を得ている。

藷者も Lemberg, R. にならい, 犬の同一赤血球 液を二分し，一方はこのまま上記の抽出操作を行 い，他方には絬晶 biliverdin $300 \mu \mathrm{g}$ を $1 \mathrm{ml}$ の稀 ammonia 水に溶解して溶血直前に加えた後同栐の 抽出操作を行つた。 その結果, 前者の試料からは 
Fig. 6. Schematic Presentation of the Apparatus for the Extraction of Bile Pigments in the Absence of Air.

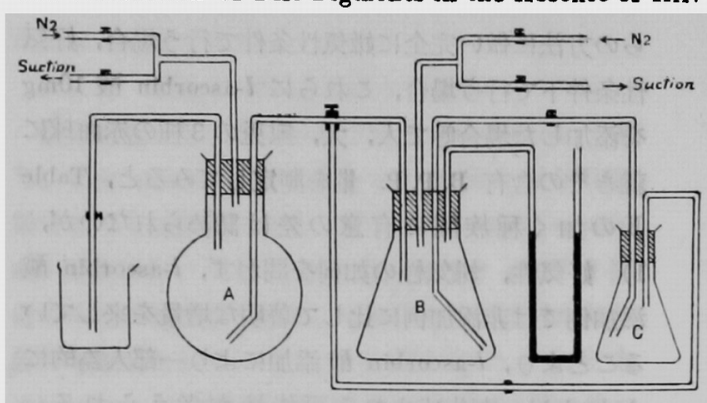

$48.4 \mu \mathrm{g}$, 後者の試料からは $254.2 \mu \mathrm{g}$ の胆汁色素 が得られたが，その差 $205.8 \mu \mathrm{g}$ は添加 biliverdin が再び抽出されたことになり，この冒は添加聂の70 名に相当する。

Lemberg, R. は抽出した胆汁色菜の量からこれの 由来した bile pigment-hemoglobin の総量を求め るために一定の因子を算出している。 三れに做つて 藻者の场合の因子を計算すると

$$
\frac{100}{70} \cdot \frac{100}{11.5} \cdot \frac{16700}{584}=355.2
$$

となる。

かくて上述の $48.7 \mu \mathrm{g}$ の胆汁色索は $17.2 \mathrm{mg}$ の bile pigment-hemoglobin に相当する. 用いた犬の packed erythrocyte $10 \mathrm{ml}$ は hemoglobin $2030 \mathrm{mg}$ を今有しているので，二の0.8若が bile pigmenthemoglobinであるに過ぎないが,この值は Lemberg, R. の求めた0.9名とかなり近似の值である。

\section{III，実 験 成緷}

\section{1. 各程動物の正常值}

健康な人，家冤，犬，牛の赤血球について正常值 を求めると Table III の成績を得た。その結果は種 族䦥に有意の差を認め難い.

又 biliverdin と bilipurpurin との量的な割合は 非常に区々て，一定の傾向は認め難い，求めた值に Lemberg 氏因子を乗ずると hemoglobin $1 \mathrm{~g}$ 当りの bile pigment-hemoglobin の含有量になるが, この 場合人赤血球では平均 $6.3 \mathrm{mg}$ で含有率は 0.6396 なる. 以下家兔・犬・牛の赤血球ではそれぞれ $5.9 \mathrm{mg}$ で $0.59 \%, 5.2 \mathrm{mg}$ で $0.52 \%, 5.4 \mathrm{mg}$ で 0.54タ大になる，全係族を通じ0.52〜0.63\%の箝囲に ある.

\section{2. ascorbin 酸添加保存の影}

健康犬の股動脈より然菌的に A. C. D. 液中に 採血し，更に実験中す無菌的に維持する目的て penicillin を少量加えた，

この血液に予め $l$-ascorbin 酸結晶をその $20 \mathrm{ml}$ 当り $100 \mathrm{mg}$ の割合で生理的食塩水 に溶解し $1 \mathrm{~N} \mathrm{NaOH}$ 生理的食塩水溶液て 中和して調製した海洨を加え $l$-ascorbin 酸 添加犬赤血球液を作り，てれを予め隇菌し た 4 つの三角コルベンに $20 \mathrm{ml}$ 宛分注し 綿栓の後, $37^{\circ} \mathrm{C}$ 硘卵器中に各 $2,6,12,24$

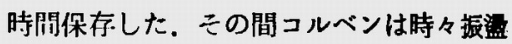
し内容の均等混和に努めた。

Table III. Normal Values of Bile Pigments in Normal Erythrocytes

\begin{tabular}{|c|c|c|c|c|}
\hline \multirow{2}{*}{ Species } & \multirow{2}{*}{ No. } & \multicolumn{3}{|c|}{ Bile Pigments $(\mu \mathrm{g} / \mathrm{Hb})$} \\
\hline & & total & biliverdin & $\begin{array}{l}\text { bilipurpu- } \\
\text { rin }\end{array}$ \\
\hline \multirow{6}{*}{$\operatorname{man}$} & 1 & 21.46 & 12.90 & 8.56 \\
\hline & 2 & 13.98 & 6.54 & 7.44 \\
\hline & 3 & 13.08 & 6.54 & 6.54 \\
\hline & 4 & 23.26 & 2.90 & 20.36 \\
\hline & 5 & 16.55 & 6.48 & 10.07 \\
\hline & mean & \multicolumn{3}{|l|}{17.66} \\
\hline \multirow{6}{*}{ rabbit } & 1 & 21.36 & 0.82 & 20.54 \\
\hline & 2 & 15.24 & 1.61 & 13.63 \\
\hline & 3 & 14.29 & 5.08 & 9.21 \\
\hline & 4 & 15.70 & 6.42 & 9.28 \\
\hline & 5 & 16.51 & 6.46 & 10.05 \\
\hline & mean & \multicolumn{3}{|l|}{16.62} \\
\hline \multirow{6}{*}{$\operatorname{dog}$} & 1 & 12.52 & 2.18 & 10.34 \\
\hline & 2 & 11.75 & 2.32 & 9.43 \\
\hline & 3 & 19.80 & 0.60 & 19.20 \\
\hline & 4 & 14.42 & 3.65 & 10.77 \\
\hline & 5 & 14.38 & 10.00 & 4.38 \\
\hline & mean & \multicolumn{3}{|l|}{14.57} \\
\hline \multirow{3}{*}{ cattle } & 1 & 13.73 & 7.25 & 6.48 \\
\hline & 2 & 16.69 & 6.53 & 10.16 \\
\hline & mean & \multicolumn{3}{|l|}{15.21} \\
\hline
\end{tabular}

一定時䦗程過後は赤血球を数回生理的食塩水で 㳐淮し赤血球浮游液中或は赤血球膜面附着の $l$-ascorbin 酸を除外し, $l$-ascorbin 酸が抽出操作の 段階まで混入しないように努めた後，赤血球内 B. P. P. 量を測定した。その成績は Table IV, Fig. 7 の如くである。

即ち第 1,2 例共に早期に著しい増量を起す. 特 
Table IV. Changes observed in the Blood of Dogs after the Incubation

at $37^{\circ} \mathrm{C}$ together with 1-Ascorbic Acid.

$(l$-ascorbic acid $100 \mathrm{mg}$ per $20 \mathrm{ml}$ of blood)

\begin{tabular}{|c|c|c|c|c|c|c|}
\hline \multirow{2}{*}{ Dog } & \multirow{2}{*}{, } & \multirow{2}{*}{ Before } & & & & \\
\hline & & & 2 & 6 & 12 & 24 hrs. \\
\hline \multirow{4}{*}{ No. 1} & Total Bile Pigments $(\mu \mathrm{g} / \mathrm{Hb})$ & 13.79 & 27.84 & 50.45 & 42.15 & 40.14 \\
\hline & Biliverdin & 8.76 & 15.29 & 30.67 & 25.52 & 26.46 \\
\hline & Bilipurpurin & 5.03 & 12.55 & 19.78 & 16.63 & 13.68 \\
\hline & E. S. $\mathrm{Fe}^{*}(\mathrm{mg} / \mathrm{Hb})$ & 0.12 & 0.13 & 0.18 & 0.17 & 0.16 \\
\hline \multirow{5}{*}{ No. 2} & Total Bile Pigmenta $\left(\mu_{g} / \mathrm{Hb}\right)$ & 14.42 & 24.81 & 41.26 & 1140.70 & 1048.72 \\
\hline & Biliverdin & 8.77 & 14.92 & 24.36 & 1052.17 & 956.95 \\
\hline & Bilipurpurin & 5.65 & 9.89 & 16.90 & 88.53 & 91.77 \\
\hline & E. S. Fe $(\mathrm{mg} / \mathrm{Hb})$ & 0.18 & 0.17 & 0.19 & 0.29 & 0.33 \\
\hline & Hemoglobin (g/d1) & 11.8 & 10.2 & 10.2 & 9.2 & 10.5 \\
\hline
\end{tabular}

* E. S. Fe : Easily Split off Blood Iron.

Fig. 7. Hematological and Chemical Changes in the Blood of Dog after the Incubation at $37^{\circ} \mathrm{C}$ together with 1-Ascorbic Acid ( $l$-ascorbic acid $100 \mathrm{mg}$ per $20 \mathrm{ml}$ of blood)

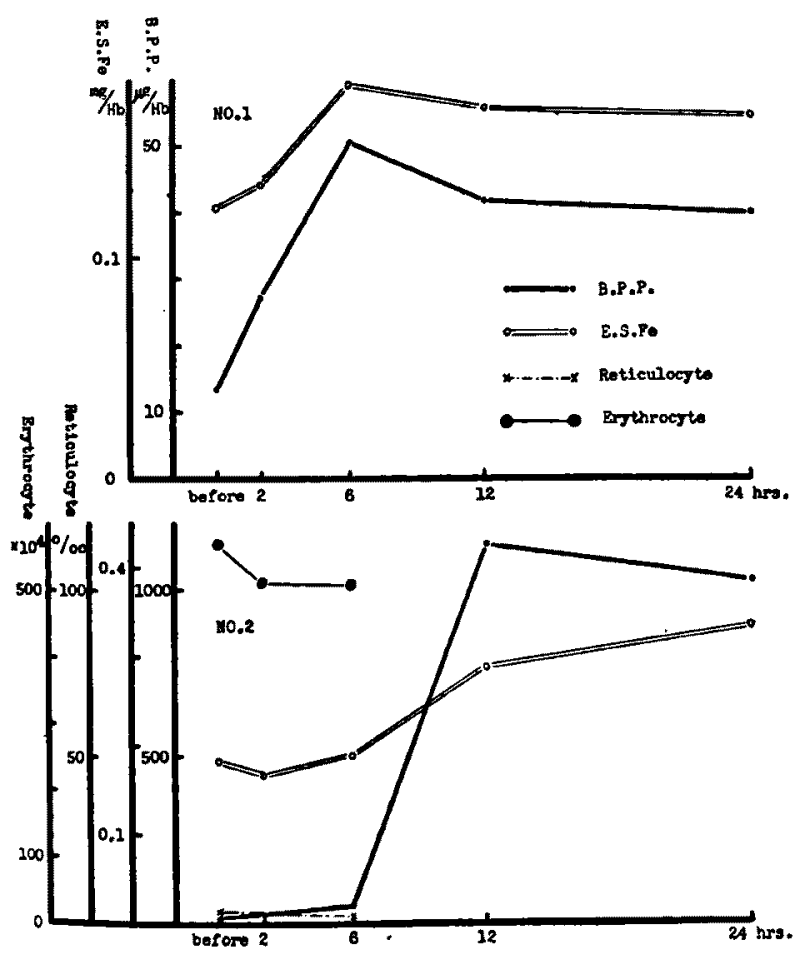

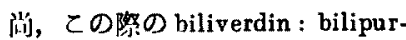
purin の比は正常値に比してかな り大である。

\section{3. 塩酸 phenylhydraxine 注射による就撆}

健应成熟家秃儿塧酸 phenylhydrazineを体重 $1 \mathrm{~kg}$ 当り $50 \mathrm{mg}$ 皮下注射し，以後 4 㭙閒，1，2， 4 日目に採血し，之の赤血球内 B.P.P. を測定した，その成績は Table V, Fig. 8 に示す通りで ある. 即ち第 $1 ， 2 ， 3$ 例共住注射 後 4 時開目より著增を認めるが， その程度は区々である，又上昇の 速度，頂点の時期，減少の速度に あ区々の埸合があるが， B. P. P. の頂点は他の 2 例を含めて 5 例に 於いて1〜2日が㱠んどである。 E.S. Fe 6大体平行的な関係に あり，有意な経過を示す，尚，乙 の際第 3 例では注射後速やかに著 明な繥状赤血球增多が起る拘ら ず B.P.P. 加增加している.

\section{4. 保存による影部}

㯬康犬の股䟭脈より淔接に血液 飞第 2 例の增加の制合は極めて大である，又赤血球 内 E.S.Feの経過も大体 B.P.P. と同様である が，B.P.P. の增加の割合に比して䢘かに小であ 3.

銀行より提供の探血䇴に热菌的に探血した，寉器に は予め A.C.D. 液が $30 \mathrm{ml}$ 入つており，その中に 血液 $100 \sim 150 \mathrm{ml}$ を入れた，をれを $4^{\circ} \mathrm{C}$ の水空に 保存し，1週閒間隔で必要量（約 $20 \mathrm{ml}$ ) 取り出し 
Table V. Changes observed in the Blood of Rabbits following the Administration of Phenylhydrazine $\mathrm{HCl}$. (phenylhydrazine $\mathrm{HCl} 50 \mathrm{mg}$ pro kg.)

\begin{tabular}{|c|c|c|c|c|c|c|}
\hline \multirow{2}{*}{ Rabbit } & & \multirow{2}{*}{ Before } & & & & \\
\hline & & & $4 \mathrm{hrs}$. & 1 & 2 & 4 days \\
\hline \multirow{4}{*}{ No. 1} & Total Bile Pigments $(\mu \mathrm{g} / \mathrm{Hb})$ & 16.16 & 222.96 & 230.50 & 75.48 & 40.95 \\
\hline & Biliverdin & 5.47 & 103.06 & 130.51 & 30.90 & 18.59 \\
\hline & Bilipurpurin & 11.07 & 119.90 & 99.99 & 44.56 & 22.36 \\
\hline & E. S. $F e^{* 1}(\mathrm{mg} / \mathrm{Hb})$ & 0.15 & 0.20 & 0.18 & 0.16 & 0.13 \\
\hline \multirow{4}{*}{ No. 2} & Total Bile Pigments $(\mu \mathrm{g} / \mathrm{Hd})$ & 14.29 & 152.20 & 50.26 & 35.84 & \\
\hline & Biliverdin & 5.08 & 91.30 & 31.47 & 18.50 & \\
\hline & Bilipurpurin & 9.21 & 60.90 & 18.79 & 17.34 & \\
\hline & E. S. $\mathrm{Fe}^{* 1}(\mathrm{mg} / \mathrm{Hb})$ & 0.13 & 0.20 & 0.14 & 0.13 & \\
\hline \multirow{9}{*}{ No. 3} & Total Bile Pigments $(\mu \mathrm{g} / \mathrm{Hb})$ & 21.36 & 36.26 & 30.97 & 56.78 & 31.86 \\
\hline & Biliverdin & 0.82 & 10.28 & 2.47 & 8.80 & 1.29 \\
\hline & Bilipurpurin & 20.54 & 25.98 & 28.50 & 47.98 & 30.57 \\
\hline & E. S. $F \mathrm{e}^{* 1}(\mathrm{mg} / \mathrm{Hb})$ & 0.14 & 0.19 & 0.20 & 0.22 & 0.16 \\
\hline & Erythrocyte $(\times 104)$ & 672 & 557 & 481 & 331 & 310 \\
\hline & Reticulocyte $\left(\%_{0}\right)$ & 7 & 26 & 124 & 85 & 112 \\
\hline & Hemoglobin $(\mathrm{g}, \mathrm{dl})$ & 14.1 & 12.2 & 11.0 & 7.7 & 7.1 \\
\hline & \multicolumn{6}{|c|}{$\begin{array}{l}\text { Osmotic Fragility of Erythrocyte*2 } 0.40 \sim 0.520 .36 \sim 0.500 .40 \sim 0.50 \\
(6)\end{array}$} \\
\hline & Serum Bilirubin $(\mathrm{mg} / \mathrm{dl})$ & $0.71(0)$ & $0.90(0.14)$ & $0.52(0)$ & $0.52(0)$ & $0.71(0.14)$ \\
\hline
\end{tabular}

*1 E. S. Fe : Easily Split off Blood Iron.

*2 $\mathscr{t}$ : Concentration of $\mathrm{NaCl}$ Solution.

Fig. 8. Hematologicl and Chemical Changes in the Blood of

Rabbits following the Administration of Phenglhydrazine $\mathrm{HCl}$
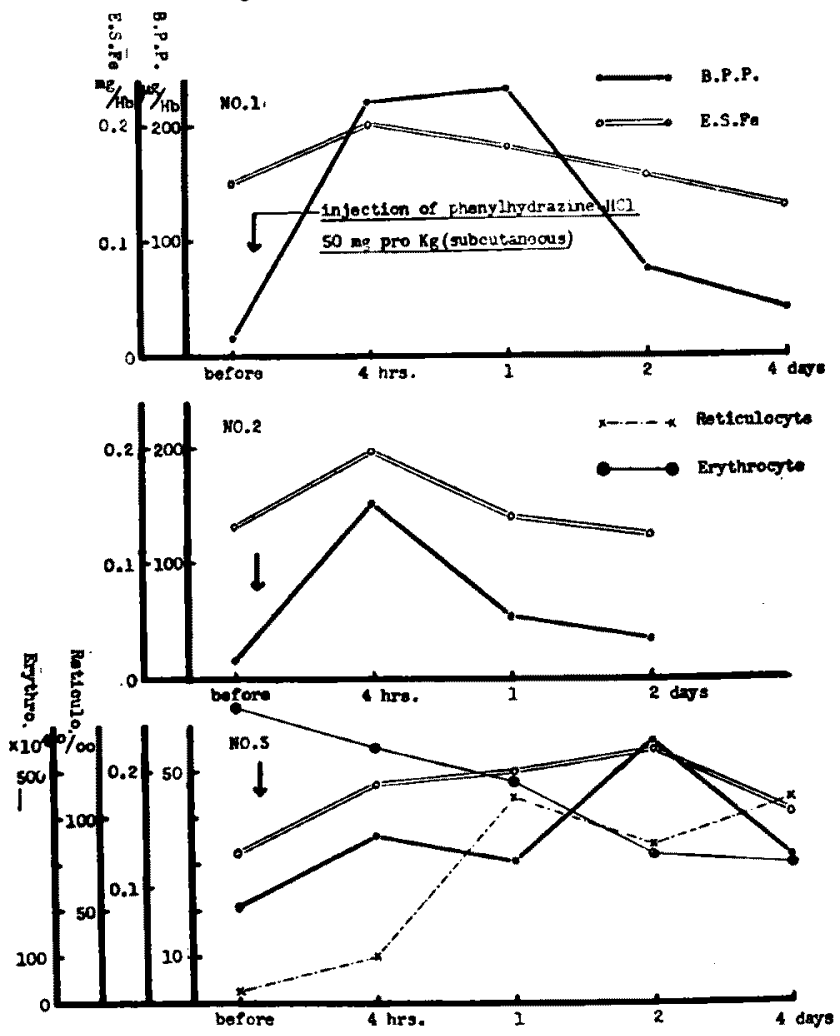
て試料とした。

その成积は Table VI, Fig. 9 の如くである. 即 ち第 $1 ， 2 ， 3 ， 4$ 例共に保存により時間之共に B.P.P. は渐増の傾向を示している. 各例の最終測 定値の增加率は第 1 例より湎に177\%，208\%，174 タ， 274 名である. 特に第 4 例は他の 3 洌に比して 增加率加大であるか，てれは後述する理由により㭃 若赤血球の增加している血液を使用したためと考え られる.E.S.Fe あ多少の增減を繰返えすが，

B.P.P. に伴つて増加している.

第 3，4 例では赤血球数, 網状赤血球数, 血色菜

量，赤血球抵抗等を同時に测定してあるが，それに よると赤血球数は保存により㱠んよ゙变化していない。 しかも赤血球抵抗の低下する第 4 週以後でも減少は 殆んと見られない.しかしながら，形態学的には金

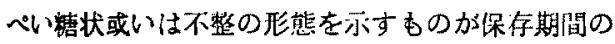

延長と共に增加することを認好る。

\section{5. 演血による影雷}

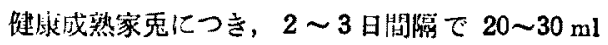
宛鴧洫を行い，演血血波につき諸硅の測定を施行し た結果, Table VI, Fig. 10 の成續を得た。即ち第 1，2，3例に於いては，淊血の反覆施行により，赤 血球数，血色䇣量は急速江減少するが，それと全く 反対に網状赤血球数は著しく増加する.

、その際 B.P.P. の推移は赤血球数のそれと大体 平行している. 即与幼若赤血球の增加する時期, 乙 れは又成熟乃至老朽赤血球の割合の減少する時期で あるが， B.P.P. は減少し，二の反対の時期には增 加することになる。

E.S. Fe B. B.P. 上活行的に推移するが，第 2 例に於いて，特に顕著でる。

Table II. Changes observed in the Stored Blood of Dogs

(stored at $4^{\circ} \mathrm{C}$ in A. C. D. Solution)

\begin{tabular}{|c|c|c|c|c|c|c|c|}
\hline \multirow{2}{*}{ Dog } & & \multirow{2}{*}{ Before } & & & & & \\
\hline & & & 1 & 2 & 3 & 4 & 5 weeks \\
\hline \multirow{4}{*}{ No. 1} & Total Bile Pigments $(\mu \mathrm{g} / \mathrm{Hb})$ & 14.38 & 21.82 & 20.12 & 25.50 & & \\
\hline & Biliverdin & 10.50 & 12.89 & 12.67 & 15.30 & & \\
\hline & Bilipurpurin & 3.88 & 8.93 & 8.45 & 10.20 & & \\
\hline & E.S. Fe $* 1(\mathrm{mg} / \mathrm{Hb})$ & 0.13 & 0.14 & 0.15 & 0.17 & & \\
\hline \multirow{4}{*}{ No. 2} & Total Bile Pigments $(\mu \mathrm{g}, \mathrm{Hb})$ & 15.00 & 20.87 & 26.43 & 31.20 & & \\
\hline & Biliverdin & 11.16 & 12.95 & 19.03 & 15.50 & & \\
\hline & Bilipurpurin & 3.84 & 7.94 & 7.40 & 15.70 & & \\
\hline & E. S. Fe *1 & 0.12 & 0.14 & 0.17 & 0.16 & & \\
\hline \multirow{6}{*}{ No. 3} & Total Bile Pigments $\left(\mu_{\mathrm{g}} / \mathrm{Hb}\right)$ & 11.75 & 15.36 & 11.48 & 15.80 & 20.50 & \\
\hline & Biliverdin & 2.43 & 1.38 & 2.01 & 1.92 & 3.70 & \\
\hline & Bilipurpurin & 9.32 & 13.98 & 9.47 & 13.98 & 16.80 & \\
\hline & E. S. Fe $\mathbf{e}^{* 1}$ & 0.10 & 0.16 & 0.12 & 0.17 & 0.11 & \\
\hline & Erythrocyte $(\times 104)$ & 492 & 469 & 433 & 513 & 515 & \\
\hline & Hemoglobin $(\mathrm{g} / \mathrm{dl})$ & 10.8 & 10.8 & 13.0 & 11.2 & 11.2 & - \\
\hline \multirow{7}{*}{ No. 4} & Total Bile Pigments $(\mu \mathrm{g} / \mathrm{Hb})$ & 19.80 & 15.33 & 37.34 & 40.37 & 52.01 & 54.54 \\
\hline & Biliverdin & 0.60 & 3.44 & 21.85 & 27.85 & 29.35 & 38.18 \\
\hline & Bilipurpurin & 19.20 & 11.89 & 15.49 & 12.52 & 22.66 & 15.36 \\
\hline & E.S. Fe ${ }^{* 1}(\mathrm{mg} / \mathrm{Hb})$ & 0.17 & 0.17 & 0.16 & 0.16 & 0.19 & 0.19 \\
\hline & Erythrocyte $\left(\times 10^{4}\right)$ & 571 & 516 & 529 & 587 & 550 & 533 \\
\hline & Hemoglobin $(\mathrm{g} / \mathrm{dl})$ & 12.6 & 12.2 & 11.8 & 12.2 & 11.8 & 12. 20 \\
\hline & $\begin{array}{l}\text { Osmotic Fragility of Erythrocyte } \\
(\mathscr{6})\end{array}$ & 0.43 & 0.43 & 0.44 & 0.43 & 0.60 & 0.60 \\
\hline
\end{tabular}

*1 E.S. Fe : Easily Split off Blood Iron

*2 $\%$ : Concentration of $\mathrm{NaCl}$ Solution (by I'ennel's Method) 
Fig. 9. Hematological and Chemical Changes in the Stored Blood of Dogs.

(stored at $4^{\circ} \mathrm{C}$ in A.C. D. solution)

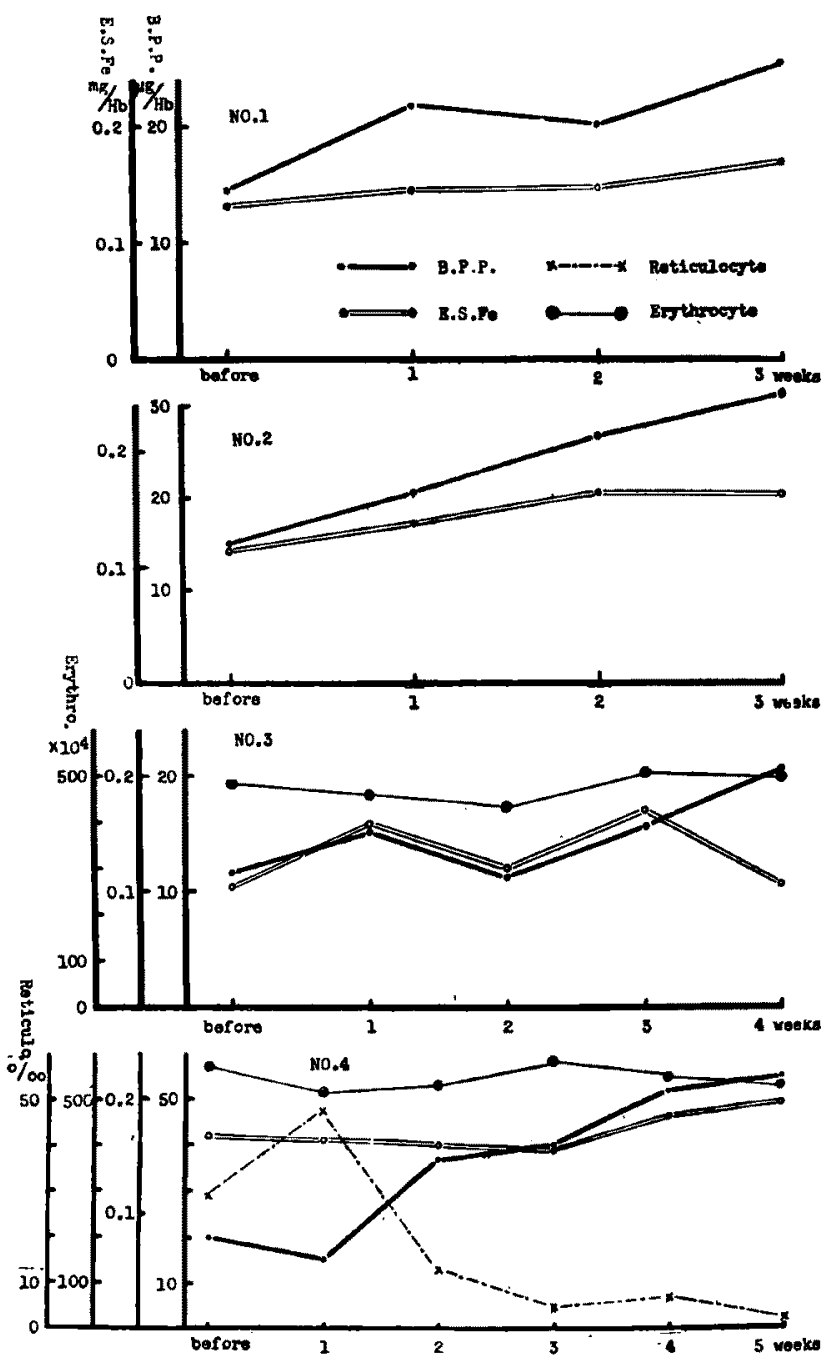

Table VI. Changes observed in the Blood of Phlebotomized Anemic. Rabbits.

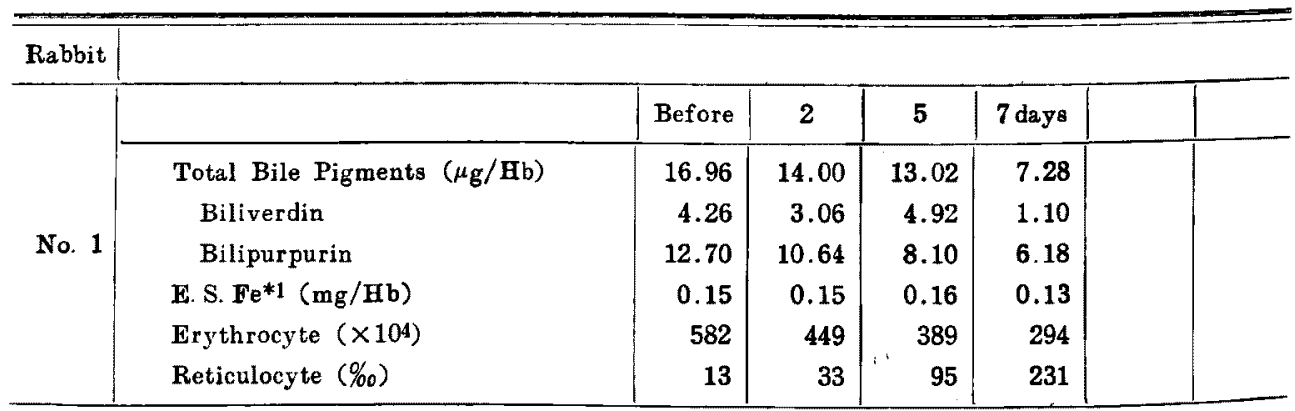




\begin{tabular}{|c|c|c|c|c|c|c|c|}
\hline \multirow{8}{*}{ No. 2} & & Before & 2 & 4 & 7 & 10 & 14days \\
\hline & Total Bile Pigments $(\mu \mathrm{g} / \mathrm{Hb})$ & 15.24 & 14.57 & 17.91 & 9.83 & 20.37 & 20.23 \\
\hline & Biliverdin & 1.61 & 0.83 & 2.10 & 1.47 & 1.48 & 3.12 \\
\hline & Bilipurpurin & 13.63 & 13.74 & 15.81 & 8.36 & 18.89 & 17.11 \\
\hline & E. S. $\mathrm{Fe}^{* 1}(\mathrm{mg} / \mathrm{Hb})$ & 0.23 & 0.15 & 0.12 & 0.10 & 0.11 & 0.16 \\
\hline & Erythrocyte $\left(\times 10^{4}\right)$ & 625 & 512 & 498 & 364 & 422 & 496 \\
\hline & Reticulocyte $\left(\%_{0}\right)$ & 10 & 21 & 113 & 172 & 195 & 58 \\
\hline & Hemoglobin $(\mathrm{g} / \mathrm{dl})$ & 14.4 & 13.0 & 10.5 & 9.6 & 10.5 & 11.5 \\
\hline \multirow{8}{*}{ No. 3} & & Before & 4 & 6 & 13 & 18days & \\
\hline & Total Bile Pigments $(\mu \mathrm{g} / \mathrm{Hb})$ & 14.29 & 16.27 & 13.72 & 20.94 & 14.07 & \\
\hline & Biliverdin & 5.08 & 4.00 & 2.60 & 9.29 & 2.89 & \\
\hline & Bilipurpurin & 9.21 & 12.27 & 11.12 & 11.65 & 11.18 & \\
\hline & E. S. Fe*l (mg/Hb) & 0.16 & 0.16 & 0.14 & 0.16 & 0.14 & \\
\hline & Erythrocyte $(\times 104)$ & 544 & 413 & 359 & 517 & 434 & \\
\hline & Reticulocyte $\left(\%_{\infty}\right)$ & 91 & 52 & 95 & 75 & 71 & \\
\hline & Hemoglobin $(\mathrm{g} / \mathrm{dl})$ & 3.4 & 15.2 & 10.8 & 11.8 & 10.5 & \\
\hline
\end{tabular}

*1 E, S. Fe : Easily Split off Blood Iron

Fig. 10. Hematological and Chemical Changes in the Blood of Phlebotomized Anemic Rabbits.
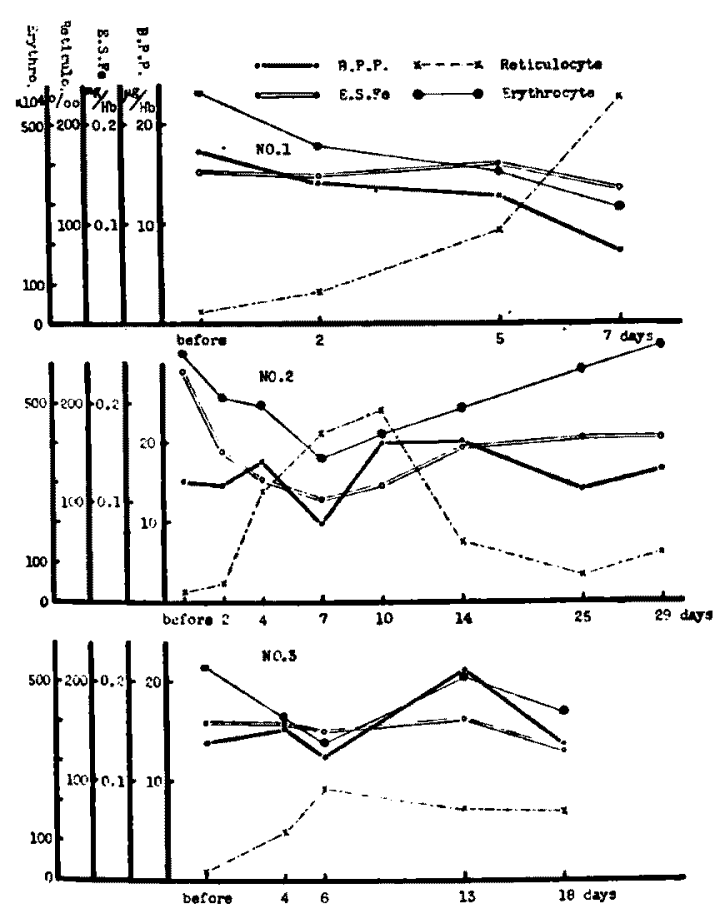

IV.緮括並びに考按

人，家鬼，犬，牛等の健康生存赤血球内に於いて， 每常 B.P.P. 加抽出検出されることが明らかるさ つた,
さて，赤血球内 B.P.P. の搔山法は初め Lemberg, R. et al. 2) の考案による方法に よつたのであるが, 同法では抽出する biliverdin の酸化を防ぐための antioxidant と して $l$-ascorbin 酸を血液 $10 \mathrm{ml}$ に対し $10 \mathrm{mg}$ の割合で醋酸好理の直前に添加している.

しかしこれは Gardikas, C. et al. 16) の指摘 する如く $l$-ascorbin 酸亡 oxyhemoglobin 之 のcoupled oxidationにより choleglobin を生 成し，とれが抽出操作を経て胆汁色涪とし て抽山测定される可能性がある. Gardikas, C. らはこれを伹止するため $l$-ascorbin 酸を 加えないで突空山或いは inert gas 䒕満下 という嫌氮性条件下で同椂の於みを行つて いる、役はこういう嫌気性条件下の抽山に より次の side reaction 力防方机たレいつ

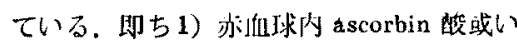
は glutation $と の$ coupled oxidation によ む oxyhemoglobin からの choleglobinの 生放. 2) 外気中の $\mathrm{O}_{2}$ 或は oxyhemoglobin の酸変性により遊離した活性酸染によ る biliverdin $の$ biliviolin への酸化. 3) choleglobin $\circlearrowleft$ green pigment への䒨北の 3 点でち จ.

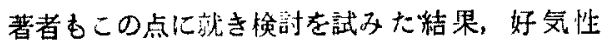
(空気中)，嫌気性（N2gas 光満下）の何扎を問わす，

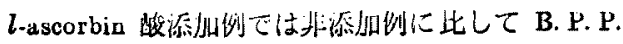


昌壮

の総息は著明に增加し，二の増加率は好気性の 1 例 では114名，螊気性の 2 例では54\%,55\%である. 又 biliverdin bilipurpurin $の$ 比む非添加例に比して 著しく大きく，前者は $1.54 ， 1.34 ， 1.77$ で 1 より 大きく，後者は $0.11 ， 0.76 ， 0.11 ， 0.62$ で 1 より 小である. これは添加 $l$-ascorbin 酸により biliverdin の bilipurpurin 八の酸化が明らか抑制されて いるととを示すむのである. とれに対し，非添加例 では好気性，娍気性の何れも收量に有意の差は認子 難いが, biliverdin . bilipurpurin $の$ 比が好気性下 では嫌気性下に比へでさい，即ち前者では0.11て あるのに，後者では $0.62 ， 0.69 ， 0.72$ である.こ れは好気性の方が biliverdin の bilipurpurin への 酸化が起り易いことを意昧する。

従つて B.P.P. の測定には嫌気性条件下で， l-ascorbin 酸添加加最も適当すおるとととなる。 その際 B.P.P. の測定を Lemberg, R. の方法2)14) により biliverdin の形のみで行うことは不会理で， 全 B.P.P. を bilipurpurin 画鉊錯监の北で测定す る Gardikas, C. 17) の今法加妥当であると考える.

但し，ここで bilipurpurin 亚徐錯塩と呼称した が， chloroform 抽出液に醋酸严雓と沃度を加えて発 する赤紅色の螢光は柴外線照射により急速に緑色に 変わるが，この緑色螢光の物質はその螢光分光特性 が 516 520 mu であり, 又吸収極大は $510 \mathrm{~m} \mu$ に あり choleterin の亜鉛錯塭であると考えられる。

更にこの程色の螢光は紫外線照射を続けることに

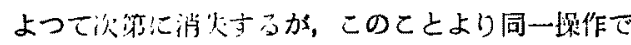
choleterin は次第に変化することる考えられる。

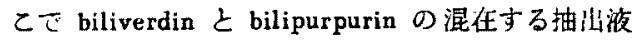
の塯合には， biliverdin と bilipurpurin のたれた れからの choleterin 生成と choleterin 分解では簧

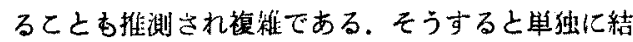
晶 biliverdin の標準液を用いて調製した娭量曲線 ては拙出液による測定に適合しないかとも考えられ るか， bilipurpurin を純枠得ることは不可能で， それ等の量的，特間的関係を㭪整する訳にはゆかな いので，本論文は便宜的に biliverdin 標集液によ る検量曲縓を使用した。

回収試験す上記の意账で本将は biliverdin, bilipurpurin のてれぞれにいいて求めるてきであ心が, 諸種の困雚を伴うので biliverdin のみ添加した場

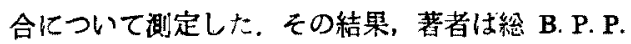
にして70\%という值を得たか，その绦の biliverdin 及び bilipurpurin の它分比はそれぞれ84\%と16\%
であ、添加した biliverdin の約16\%が bilipurpurinに移行したことになる。この俌は空気中にて l-ascorbin 酸添加の条件下で行つた Lemberg, R. 19) の求めた回収率52名に比してかなり高く，Gardikas, C. に準じて行つた本法の方が俊れているといい得 るであろう。

かくて Lemberg, R. 14) 亿做つて求めた B.P.P. の母体の bile pigment-hemoglobin の星に㬇算する ための因子（Lemberg 氏因子）は355.2となり，

Lemberg, R. の得た 480 亿比して小さく，换算㭙の 㮸差加小さく好都合であうた。

さて，人赤血球中に含有する B.P.P. 量につい ては Lemberg，R，14) らは好気性下， $l$-ascorbin 酸添 加の条件下での正常值として $6.2 \mu \mathrm{g} / \mathrm{ml}$ (biliverdin $4.6 \mu \mathrm{g} / \mathrm{ml}+$ biliviolin $1.6 \mu \mathrm{g} / \mathrm{ml})$ を挙げており， これを Lemberg 氏因子を用いて計算すると含有 hemoglobin 00.996 に相当する. この同じ武料次 き好気性下， $l$-ascorbin 酸添加の場合之非添加の場 合を比较すると，前者は $46 \mu \mathrm{g} / 8.75 \mathrm{ml}(23+23)$ ， 後者は $66.2 \mu \mathrm{g} / 8.75 \mathrm{ml}(45.7+20.5)$ て，それぞ 机含有 hemoglobin $90.8 \%$ 及び1.1\%に相当した。 又 Garbikas, C. の批判に対して嫌気性下， $l$-ascorbin 酸非添加で行つた成績では 7 9 $\mu \mathrm{g} / \mathrm{ml}$ であ、 添加洌より大であることより choleglobin'の竐明は 測定中に生ずる人為的生成産物でなとする立場を 堅持した15).

次に Gardikas, C. は健选人之病人の10余洌につい て Lemberg, R. の操作を嫌気性下に行い，比色定 量を行つたか， 3 例以外では choleglobin，を検出し 得なかつたため $l$-ascorbin 酸添加による choleglobin の人為的生成を推谕した16）か， その後 Lemberg, $\mathbf{R}$. の提条を受けて万法の收良を行い，螢光定量法を用 いて $24.7 \mu \mathrm{g} / \mathrm{ml}$ という倠を仿た。これは Lemberg 氏因子より計算してみると，含有 hemoglobin の $0.17 \%$ にすぎない17).

著者の今法て求めた各任较物の正常值は平均 して人 : $17.66 \mu \mathrm{g} / \mathrm{Hb}$, 家兔: $16.62 \mu \mathrm{g} / \mathrm{Hb}$ ，犬： $14.57 \mu \mathrm{g} / \mathrm{Hb}$ ，牛 : $15.21 \mu \mathrm{g} / \mathrm{Hb}$ であり，種境によ り若干の差はあるが有意と判断し難い，試料として 用いた packed erythrocytes は血色菜竖度にして約 $20 \mathrm{~g} / \mathrm{dl}$ 前徭であるのて， $\mathrm{ml}$ 当りに蔇算与ると 2 $4 \mu \mathrm{g} / \mathrm{ml}$ となり， $l$-ascorbin 酸添加の条件下で行つ た Lemberg，R．の值より低值を示し，は伊同一条 件下で行つた Gardikas,C. の值に近い，更化含有

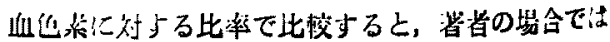


比率が0.52 0.63\%であり，Lemberg，R. の得た 值と Gardikas，C.のそれとの中間に位する。

赤血球を放置し，或いは -ascorbin 酸その他の 薬品を作用させて赤血球内に於りる血色菜の崩罗を 泟明しようとする試みは緒言比於ても既述の如く教 宗に於ても乾》，中+弗11)，北川(2)，高林(9)，川 口8)，田村9）らにより行われた。

先つ, l-ascorbin 酸添加保有した大赤血球ては早. 期より赤血球内の B.P.P. の極めて渚明な增量を 惹起するが，E.S.Feの経過は左程著しくない。

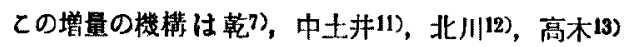
等の説によれば $l$-ascorbin 酸が赤血球膜を通じて 赤血球内に入り，その自䣬化により血色瑟の分解を 起すといわれるが，その説は妥当なものと考える。 著者が用いた $l$-ascorbin 酸蔽度估高木の記诚してい るl-ascorbin 酸のそれに比してかなり低溜度であ ろが、それですなお著しく大星の biliverdin を生 成する点は注目に洒する。

㙁酸 phenylhydrazine 注射家兔赤血球において 6注射後著しく早期化增加を表し，4時䦕乃至 2 日 目に最大值に達し，又次第に減少する．この阥の E.S. Fe の態度は網状赤血球増多で表される新生赤 血球の増加が相当著明にあるに拘らず尚，B.P. P. と共隹移している。即ちこの場合は E.S.Feか B.P.P. 乙高い相関関係を有し，新生赤血球中には 一部速やかに含有血色素の分解を来すすのがあるて とが撒定される。このことは㴼血寊血例について更 に考察される.

赤血球保存例では多少の增隇があるが，時間の経 過と共飞 B.P.P. 及び E.S. Fe は渐增の㑯向を 示す. 特に3週以後に於て堌加が著しい. 教字 乾》はE.S.Feの側加ら検討し，その增加が一過 性であるととより赤血球内に生成する verdohemoglobin は時問の経過と共に酸に上る鉄遊触力困䊮に なるのであろうと推測しているか， B.P.P. そのあ のか次第に增加すると之は明らかである、Löhr, G.W. et al. 20)の赤血球の老化汇関する研究によ れば，老化赤血球のエネルギー代謝の変化を酵素化 学的侸しらへて，赤血球の年令之特に関聯のある phosphoglyceraldehyd dehydrogenase $\ell$ glucose 6-phosphate dehydrogenase $の$ 活吽:度は $20^{\circ} \mathrm{C}$ 以下

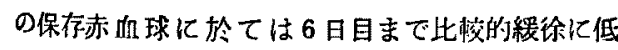
下するが7日目には完全に消失し，その時溶血を伴

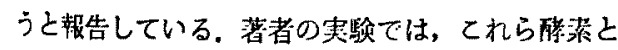
の関係をしらへていないが，B.P.P. 生成がこれら

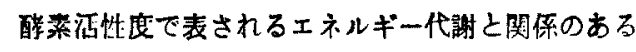
ことは想像に䧿くない，一方，吉川ら21)は保存 血液の生化学的変化を追究し, posttransfusional vitality 等の生物学的活性の減少の根底にはエネル ギー代謝活性の減弱乃至消夫があるという考えに立

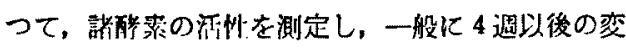
化が获明であるという紶果を得ているが，沙血は ATP レベルが全く低下し，従つて解糖作用が叔 まつてしまつてから两に 4 週後に至つても5\%にし か過きないということに注目している，著者も時閂 の経過と共に澺透下抓抗の低下は諗めるか，5週を 越えて来尚，洐血は極く軽微であり，赤血球数，血 色素灌度にす大した変化の起らないととを認めてい

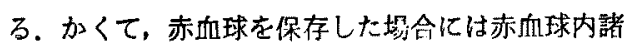

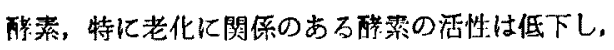

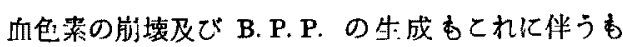
のと考えられる。しかし，淮血现䒺はこれらの変化 忠实に表睍するるのではない．

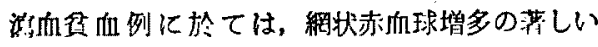
洔，即古新牛赤血球の增加した脚期に一致して B.P.P.の明らかな低下が認められ，又 E.S.Fe 卉大体平行している．先に述へた如く， B.P.P. が 赤血球の老化過程仁伴つて生成されるものとすれば， 新生赤血球の多い時期飞娍少するてとは当然であり， 更に E.S.Feの減少することより血色棌の崩塤の 減少も明らかであるが，その E.S.Feの減少は Wintrobe，M. M. et al. 22) の实験によれば, 網状 赤血球の部分に基くものであることが明らかである のて，従つて B.P.P. の減少もこの部分に基くも のと推定される。第 $2 ， 3$ 例に於いて，てれらの值

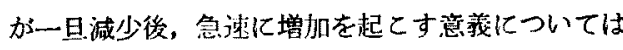
第2 編化於て詳しく諭及するが，新生赤血球内て prctopor phyrin から合成された血色弌肪一部早期 に崩塤することに基くものと考える。

\section{V. 䊅論}

赤血球内 bile pigment precursors (B.P.P.) の 微量定量法の揄驸と B.P.P. の生理的意義の解明 のため誁利の实験的孝察を行い，次の結諭を得た。

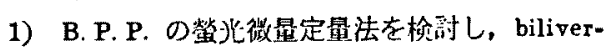
din chloroform 㴼液では $0.1 \sim 5.0 \mu \mathrm{g} / \mathrm{ml}$ の笓用 内の濃度で定星可能なととを確めた. 又その B.P.P. の定显はすべて choleterin 可錴錯塩の篮光による

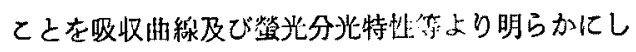
た。 
2）赤血球内 B.P.P. の抽出条件は，Lemberg， R. Kよる $l$-ascorbin 酸添加，好気性下での抽引は りは，Gardikas，C. Kよる $l$-ascorbin 酸非添加、 嫌気性下での抽山の方が合理的である。

3）冬種動物の正常赤血球内には B.P.P. 加常 に略 $15 \mu \mathrm{g} / \mathrm{Hb}$ 存存:し，秝旅開化有意の差を認め ない。

4） 大赤血球に $l$-ascorbin 酸を添加した後， $37^{\circ} \mathrm{C}$ に保存した結果, 赤血球内 B.P.P. は数㭙問以内に 著明な高值化達するが，乙れは $l$-ascorbin 酸が赤 血球中に入り choleglobin 生成に関与する結果と考 える. E.S. Fe も同様の経過を逆る.

5）家鬼に塩酸 phenylhydrazine を注射した後流 血中の赤血球内 B.P.P. は 4 時間後よりかなり上 昇し，4時閒乃至 2 日で最高値を得る. E.S. Fe あ 略々平行閊倸似ある。

\section{引用文献}

1）山戌害二：日内会誌，42：531 590, 1953.

2) Lemberg, R. \& Legge, J. W. : Aust. J. exp. Biol. med. Sci., 20: 65 68, 1942.

3) Crike, A.: Dtsch. Arch. f. Klin. Med., 164: 236 242, 1929.

4) Watson, C. J. \& Paine, J.A.: Am. J.M. Sc., 205: 493 501, 1943.

5) Barkan, G. . Z. physiol. Chem., 148: 124 154, 1925.

6) Barkan, G. \& Schales, Q. : Z. physiol. Chem., 248: 96 116, 1937.

7) 乾和彦: 医学研究, $24: 1335 \sim 1347$, 昭29,

8) 川口正光: 医学研究，27：1002 1034, 昭32.

9）田村辰士：風山医珿，71: 8343 8362, 昭34.

10）田浰博可：日血会誌，23：533 534，昭35.

11）中土并芳夫：医学研究，26：2544 2558, 昭31.

12）北川紀典：岡山医就，71：7079 7094, 阁34.

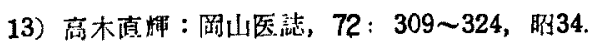

6）犬血液を A.C.D.液中に探血し $4^{\circ} \mathrm{C}$ 飞保存 した場合，赤血球内 B.P.P. は経過㭙閻之共汇次

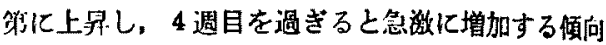
を示す．E.S.Fe 渐增する。

7）㴼血實血を起した家鬼赤血球では網状赤血球 の著增する時期に一數して B.P.P., E.S. Fe は诚 少する。

8）以上の実験成繀より，赤血球内 B.P.P.は 生理的には赤血球の老化過程に伴つて增加するすの と考えられるが, $l$-ascorbin 酸, 塩酸 phenylhydrazine 等の薬品の作用によつても增加するととが明 らかとなった。

（本論文の要旨江第20回日本血液学会総会及び第 9 回日本生化学会中国四国地方部総会飞招いて発表 した.)

14) Lemberg, R., Lockwood, W. H. \& Legge, J. W. : Biochem. J., 35 : 363 379, 1941.

15) Lemberg, R.: Nature, 163: 97, 1949.

16) Gardikas, C., Kench, J. E. \& Wilkinson, J.F.: Nature, 161: 607 608, 1948.

17) Gerdikas, C., Kench, J. E. \& Wilkinson, J. F. : Biochem. J., 46: 85 88, 1950.

18) Lemberg, R.: Biochem. J., 28 : 978 987, 1934.

19）木开友三郎：医学研究，25：1253 1272, 1955.

20) Löhr, G. W., Waller, H. D., Karges, O., Schlegel, B. \& Múller, A. A.: Klin. Wochr, 36 : $1008 \sim 1013,1958$.

21）吉川湷寿他：医学のあゆみ，29：204２13，昭 34.

22) Grinstein, M., Silva, J. A. \& Wintrobe, M. M. . J. Clin. Invest., 27 : 245 259, 1948. 


\title{
Studies on Bile Pigment Precursors in Erythrocytes
}

\section{Psrt 1. Micro-quantitative Analysis of Bile Pigment Precursors in Erythrocytes and its Alteration in}

\author{
Various Experimental Conditions
}

\author{
By \\ Shoso NAKAGAWA \\ From the First Depertment of Internal Medicine, Okayama University, Medical School \\ (Director: Prof. K. Kosaka)
}

The method of micro-quantitative analyeis of bile pigment precursors in erythrocytes was studied and various experimental observations were made for the elucidation of its physiological significance. The following results were obtained:

1. Studies of the fluorescent micro-quantitative analysis made it clear that bile pigment precursors in erythrocytes can be determined in the $0.1-5.0 \mu \mathrm{g} / \mathrm{ml}$ biliverdin chloroform solution. Observing its absorption spectrum and fluorescent spectral characteristics, it was also made clear that all the bile pigment precursors were determined by the fluorescence of choleterin zincic complex salt.

2. Gardikas' method of extracting intracorpuscular bile pigment precursors under an anaerobic condition without adding ascorbic acid proved to be better than that of $R$. Lemberg of extracting by adding ascorbic acid under an aerobic condition.

3. Among normal erythrocytes of various animals were found no significant specific differences, the amount of bile pigment precursors being about $15 \mu \mathrm{g} / \mathrm{Hb}$.

4. When dog's erythrocytes were iucubated at $37^{\circ} \mathrm{C}$. after the addition of ascorbic acid, bile pigment precursors in them attained to a remarkably great amount within several hours. This is considered to have resulted from the action of ascorbic acid in choleglobin formation in erythrocytes.

5. 4 hours after phenylhydrazine $\mathrm{HCl}$ was administered to a rabbit, the amount of bile pigment precursors in erythrocytes in circulating blood began to increase and attained to its maximum in $4-48$ hours. The amount of easily split off blood iron also increased in parallel with it.

6. When canine blood was taken in A.C. D. solution and kept at $4^{\circ} \mathrm{C}$, , the amount of bile pigment precursors in erythrocytes gradually increased with the course of time, showing a sudden increase after 4 weeks. The amount of easily split off blood iron showed a similar variations.

7. In the erythrocytes of a phlebotomized anemic rabbit, the amount of bile pigment precursors decreased at the same time as reticulocytes showed a remarkable increase. The amount of easily split off blood iron showed a similar tendency of decrease.

8. From the above results the following conclusions were drawn. Bile pigment precursors which are usually observed in normal erythrocytes are increased by chemicals such as ascorbic acid and phenylhydrazine $\mathrm{HCl}$, or by preservation, while in the case of anemia by phlebotomies where immature erythrocytes increase, the amount of bile pigment precursors decreases. Consequently, bile pigment precursors in erythrocytes physiologically increase with deterioration. 